\title{
Industrial excess heat for district heating in Denmark
}

\author{
Bühler, Fabian; Petrovic, Stefan; Karlsson, Kenneth Bernard; Elmegaard, Brian
}

Published in:

Applied Energy

Link to article, DOI:

10.1016/j.apenergy.2017.08.032

Publication date:

2017

Document Version

Peer reviewed version

Link back to DTU Orbit

Citation (APA):

Bühler, F., Petrovic, S., Karlsson, K. B., \& Elmegaard, B. (2017). Industrial excess heat for district heating in Denmark. Applied Energy, 205, 991-1001. https://doi.org/10.1016/j.apenergy.2017.08.032

\section{General rights}

Copyright and moral rights for the publications made accessible in the public portal are retained by the authors and/or other copyright owners and it is a condition of accessing publications that users recognise and abide by the legal requirements associated with these rights.

- Users may download and print one copy of any publication from the public portal for the purpose of private study or research.

- You may not further distribute the material or use it for any profit-making activity or commercial gain

- You may freely distribute the URL identifying the publication in the public portal

If you believe that this document breaches copyright please contact us providing details, and we will remove access to the work immediately and investigate your claim. 


\title{
Industrial Excess Heat for District Heating in Denmark
}

\author{
Fabian Bühler ${ }^{\mathrm{a}, *}$, Stefan Petrović ${ }^{\mathrm{b}}$, Kenneth Karlsson $^{\mathrm{b}}$, Brian Elmegaard ${ }^{\mathrm{a}}$ \\ ${ }^{a}$ Technical University of Denmark, Department of Mechanical Engineering, Nils Koppels \\ Allé, Building 403, 2800 Kgs. Lyngby, Denmark \\ ${ }^{b}$ Technical University of Denmark, Department of Management Engineering, \\ Produktionstorvet, Building 426, 2800 Kgs. Lyngby, Denmark
}

\begin{abstract}
Excess heat is available from various sources and its utilisation could reduce the primary energy use. The accessibility of this heat is however dependent amongst others on the source and sink temperature, amount and potential users in its vicinity. In this work a new method is developed which analyses excess heat sources from the industrial sector and how they could be used for district heating. This method first allocates excess heat to single production units by introducing and validating a new approach. Spatial analysis of the heat sources and consumers are then performed to evaluate the potential for using them for district heating. In this way the theoretical potential of using the excess heat for covering the heating demand of buildings is determined. Through the use of industry specific temperature profiles the heat usable directly or via heat pumps is further found. A sensitivity analysis investigates the impact of future energy efficiency measures in the industry, buildings and the district heating grid on the national potential. The results show that for the case study of Denmark, $1.36 \mathrm{TWh}$ of district heat could be provided annually with industrial excess heat from thermal processes which equals $5.1 \%$ of the current demand. More than half of this heat was found to be usable directly, without the need for a heat pump.
\end{abstract}

Keywords: excess heat, industry, district heating, heat pump, spatial analysis, GIS

\section{Introduction}

District heating has played an important role in the Danish energy past and it can be expected that it will be important in the future as well. After the First Oil Crisis in 1973, district heating based on Combined Heat and Power (CHP) plants was one of the instant measures to fight the crisis and increase the overall system efficiency. Over the last four decades, the share of District

\footnotetext{
*Principal corresponding author. Tel.: +45 45254107

Email address: fabuhl@mek.dtu.dk (Fabian Bühler)
} 


\begin{tabular}{|llll|}
\hline \multicolumn{2}{|l}{ Nomenclature } & & \\
$T$ & Temperature, ${ }^{\circ} \mathrm{C}$ & ETS & Emission Trading Scheme \\
$\Delta T$ & Temperature difference, $\mathrm{K}$ & GIS & Geographic information system \\
$\eta$ & Efficiency, - & HD & Heating Demand \\
Abbreviations & HP & Heat pump \\
CHP & Combined heat and power & yr & Year \\
COP & Coefficient of performance & Subscripts \\
CVR & Central company register & DH & District heat \\
DH & District heat & DIR & Direct \\
DKE & Denmark East & EH & Excess heat \\
DKW & Denmark West & HP & Heat pump \\
EH & Excess heat & min & Minimum \\
EPRTR & European Pollutant Release and & notDH & Not district heating \\
& Transfer Register & & \\
& & &
\end{tabular}

Heating (DH) for domestic heating in the country grew from $28 \%$ in 1972 to $54 \%$ in 2015 , thus becoming the dominant means of supply. In the same period the share of CHP plants in the district heating production increased from $28 \%$ to $67 \%$, while the share of renewable energy in DH grew from close to $0 \%$ to up to $48 \%$. The share of excess heat utilised for the supply of DH in 2015 was $2 \%$ [1]. Seen from the EU perspective, Denmark has the second highest share of citizens supplied by DH and the highest trench length of DH pipeline system in the EU [2]. The long term goal in the Danish society is to become $100 \%$ renewable in all sectors of the energy system before $2050[3,4]$. Several studies agreed that district heating should be one of the main elements of the future Danish energy system. The potential role of industrial excess heat for $\mathrm{DH}$ production is either not analysed or it is not emphasised in these studies.

Münster et al. [5] analysed three scenarios for the Danish energy system in 2025 and concluded that district heating should be expanded to cover between $55 \%$ and $57 \%$ of the heating demand. Different mixes of fuels and technologies are found to be optimal in different scenarios, but industrial excess heat was not a part of the mix in any of the scenarios. Lund et al. [6] analysed a future $100 \%$ renewable Danish energy system. Their analysis shows that it would be optimal to expand district heating to between $63 \%$ and $70 \%$ of the future heating demand. Even though excess heat is mentioned as a way to reduce fuel input and district heating is emphasised as a crucial medium for utilisation of excess heat, the role of excess heat was not analysed in more details. Möller and Lund [7] investigated the expansion of district heating into natural gas areas and rec- 
ommended to expand district heating to cover between $50 \%$ and $70 \%$ of the future heating demand. They have assumed that excess heat can cover between $83 \mathrm{GWh}$ and $153 \mathrm{GWh}$ of the net heating demand each year; this assumption is not elaborated further. Mathiesen et al. [8] proposed a vision of a $100 \%$ renewable Danish energy system in 2050 including a description of intermediate scenarios for 2015 and 2030. The proposed solution includes a drastic expansion of district heating networks until 2030. As a result, heat supply from district heating remains constant until 2050 despite significant heat savings. District heating is produced from biomass, solar heating, electric boilers and large-scale heat pumps, while industrial excess heat was not considered as an alternative. The limitation of biomass use for heating in a $100 \%$ renewable energy system was analysed by Mathiesen et al. [9]. Industrial surplus heat of $2.65 \mathrm{TWh} / \mathrm{yr}$ was included in the study and the results showed that it is economically feasible. It is also stated that district heating is important in $100 \%$ renewable energy systems as it allows the utilisation of, for instance, large-scale solar thermal plants, large-scale heat pumps and industrial surplus heat. To find the optimal heat supply for a housing community from the energy system perspective, Karlsson et al. [10] used the TIMES-DK model. District heating proved to be optimal from the system perspective in all analysed scenarios. In the scenario leading to a $100 \%$ renewable energy system before 2050 , surplus heat from biorefineries contributed to district heating production in central ${ }^{1}$ areas of East Denmark with around $4.2 \mathrm{TWh} / \mathrm{yr}$ after 2035 . These biorefineries represent investments calculated by the model and do not currently exist in Denmark. In the analysis of energy scenarios up to 2020, 2035 and 2050 published by the Danish Energy Agency [12] industrial excess heat contributed to the production of DH with annually $0.89 \mathrm{TWh}$ and $0.42 \mathrm{TWh}$ in central and decentral DH areas, respectively. Despite the existing and possible future potential of excess heat contributing to the supply of district heat, only a few works have thoroughly studied it. From the studies $[6,7,9,10,12]$ it can be further concluded that industrial excess heat brings socio-economic benefits, improves energy system efficiency and reduces primary energy demands. Since these benefits are generally desired, utilisation of $\mathrm{EH}$ for $\mathrm{DH}$ could also be interesting in countries and regions outside of Denmark.

Several studies aimed at quantifying industrial Excess Heat (EH), also referred to as waste heat, and their theoretical utilisation potential, as well as the appropriate technologies. The study by Miró et al. [13] quantified the excess heat for different countries and regions. On the European level, Naegler et al. [14] quantified the industrial heat demand by branch and temperature level. This work provides useful information for further analyses of EH in Europe. The

\footnotetext{
${ }^{1}$ In the Energy Producers Count by the Danish Energy Agency [11] district heating producers are grouped into central and decentral. Central and decentral plants supply central and decentral DH areas, respectively. The central DH areas have higher heating demands, installed capacities and transmission efficiencies compared to decentral DH areas.
} 
methods used to estimate the excess heat potential of regions, were categorised and reviewed by Brückner et al. [15]. The geographical locations of the heat sources were not specifically taken into account, however size parameters for companies (e.g. number of employees) were used in the classification. Brückner et al. [16] further investigated the utilisation of $\mathrm{EH}$ for residential heating in an urban neighbourhood. The authors concluded that the heating demand of the area cannot be covered by EH sources within its border. Excess heat should however still be accounted for when refurbishing buildings.

For Sweden, Broberg et al. [17] estimated the industrial excess heat potential for district heating networks and showed how EH investments could become profitable. Viklund and Johansson [18] reviewed the technologies for the utilisation of EH and estimated their potential for a region in Sweden. The results showed that a high potential was found for $\mathrm{DH}$, considering only heat sources above $95^{\circ} \mathrm{C}$ and no heat pumps. An analysis by Hammond and Norman [19] showed the heat recovery opportunities in the UK industry. The authors estimated the potential of excess heat from 11 industrial sectors and, based on the excess heat temperatures, showed the utilisation potential for different technologies. In addition, an analysis of heat transportation between sites with surplus heat and heating demand was performed. Another study for the UK [20] investigated the potential of using industrial excess heat for district heating. An assessment of the potential based on transmission distances was performed and it was found that approximately one third of the UK excess heat could be used for DH. A relevant study for the present work was performed by McKenna and Norman [21], where a spatial model of industrial heat loads and technical recovery potentials in the UK were presented. This study analysed heat loads and EH, grouping them into different temperature bands and estimating the recovery potential. The distribution of the heat was done mainly by site allocation based on the EU Emission Trading Scheme (ETS). The results show the geographical distribution of needed and rejected heat by industrial sector and temperature interval.

Persson et al. [22] presented a methodology to assess annual excess heat volumes from fuel combustion activities in energy and industrial facilities based on $\mathrm{CO}_{2}$ emission data from the European Pollutant Release and Transfer Register (EPRTR). This study was performed on the EU level. Their results show that the theoretical excess heat from industrial facilities in Denmark amounts to $3.4 \mathrm{TWh}$ per year. This potential includes some excess heat from thermal heat and power production as well as high-temperature sources. Since that analysis does not cover small-scale industrial facilities, they claim that $12.4 \mathrm{PJ}$ (3.4 TWh) represents a conservative estimate of the maximum annual excess heat potential. It is also stated that excess heat temperature levels and state of matter, variations of excess heat over a year as well as site-specific factors greatly influence the realisable potentials. However, these factors were not taken into account in [22]. The present study comes a step closer to the realisable potential by taking into account temperature levels of excess heat and its state of matter. A study by Lund and Persson [23] maps potential heat sources for district heating in Denmark, which could be exploited by using heat pumps. Even though they 
have focused on low-temperature sources, the theoretical (maximum) industrial excess heat potential of $3.4 \mathrm{TWh} / \mathrm{yr}$ is inherited from [22]. It is claimed that surplus heat from the industry is probably the most feasible out of all excess heat sources and it will probably be utilised before ambient heat sources.

The aim of this work is to develop a new method for determining national and regional potentials for utilising industrial excess heat for the heating of buildings with district heat. This is done by first introducing and validating a novel approach to geographically distribute industrial excess heat to single production units. Secondly, spatial analyses in GIS (Geographic Information System) are performed to link the excess heat sources with the specific district heating networks. As a result, the present study gets a step closer to a realistic potential than was found in the previous work. As the mapped industrial processes and district heating areas include temperature levels, the potential and performance of heat pumps can be further found. The overall aims can be defined as:

(i) Geographically represent industrial excess heat and district heating areas, which allows energy planners to identify potential synergies between industrial excess heat and district heating.

(ii) Present a methodology for the analysis of excess heat sources and district heating.

(iii) Show how future changes at the industrial sites, district heat consumers and heat distribution can affect the potential of $\mathrm{EH}$ for $\mathrm{DH}$.

(iv) Determine the potential for the utilisation of excess heat for district heating purposes in Denmark and differentiate the potential coverable directly or via heat pumps.

The present paper is structured as follows. Section 2 consists of the proposed methodology, describing the distribution of the excess heat, quantification of $\mathrm{DH}$ demands and linking of EH sources and DH demands performed in GIS. Section 3 presents the results and the sensitivity analysis is shown in Section 4. At the end, the validity of the methodology and results are discussed and conclusions are drawn.

\section{Methodology}

The methodology is divided into two subsections. First, the approach for determining the EH at specific production units, as well as the technical recovery is presented. In the second part, spatially detailed linking of EH sources and DH demands are presented.

\subsection{Industry analysis}

The aim of this section is to present a method to determine industrial excess heat on a sectoral level and distribute these sources to all relevant locations 
where production units are found. Furthermore, the temperature levels of the $\mathrm{EH}$ at each unit is to be determined, to allow the assessment of its utilisation potential. To account for the reduction of excess heat due to energy efficiency measures on site and the use of $\mathrm{EH}$ for $\mathrm{DH}$, an assessment of the theoretical avoidable excess heat was performed.

\subsubsection{Industrial excess heat}

Initially, the excess heat rejected to the environment was found for 22 industrial sectors which represented $80 \%$ of the 2012 energy use of the Danish manufacturing industry. This analysis only considered process energy, meaning only fuels and electricity used for e.g. drying, evaporation and melting processes. Excess heat from facilities and electric equipment, such as compressors was not considered. In the previous studies $[24,25]$ the annual excess heat in Denmark from the industry was determined and the method for quantifying $\mathrm{EH}$ explained in detail. The current study relies on the quantification and distribution, as well as industrial process information gathered in the previous studies. An overview of the 22 industrial sectors and their energy use and excess heat can be found in Table 1 for the reference year 2012 based on[1, 24, 26]. The total fuel and electricity for thermal processes are used to determine the given excess heat amounts. Among others, the thermal process related $\mathrm{CO}_{2}$ emissions are used to distribute excess heat to the production sites. The refining of oil and production of building materials represented the sectors with the largest fuel use and consequently with the highest excess heat potentials in 2012. Furthermore, these high potentials were distributed to only a few production sites in Denmark. The majority of production sites were found in the metal, food and chemical industries.

\subsubsection{Excess heat location}

The locations of the units were available from the Central Company Register (CVR). For the chosen industry sectors 2573 production sites were established. The allocation of $\mathrm{EH}$ to the single production units was performed in multiple steps to account for the different levels of information available for the individual sites. First detailed information from energy mappings were used to assign $\mathrm{EH}$ amounts to production units if such information was available. The use of actual energy use data or excess heat amounts obtained from site specific analyses has the highest accuracy. This information was very limited and it was chosen to use it for a validation of the distribution presented in Section 5.1.

The second allocation step used $\mathrm{CO}_{2}$ emissions of production units, documented as part of the E-PRTR, to allocate EH. The total $\mathrm{CO}_{2}$ emissions of each sector were found using the total primary energy input and the specific $\mathrm{CO}_{2}$ emissions of the fuels. The total $\mathrm{CO}_{2}$ emissions and the $\mathrm{CO}_{2}$ emissions of the production units, were directly correlated to the excess heat amounts. Approximately 90 production units were covered with this allocation in Denmark. The E-PRTR 
Table 1: Overview of the data used and calculated excess heat for the 22 industrial sectors for the year 2012 .

\begin{tabular}{|c|c|c|c|c|c|c|}
\hline & Industrial Sector & $\begin{array}{c}\text { Total } \\
\text { Fuel } \\
{[\mathrm{GWh} / \mathrm{yr}]}\end{array}$ & $\begin{array}{l}\text { Process } \\
\text { Electricity } \\
{[\text { GWh/yr] }}\end{array}$ & $\begin{array}{c}\text { Excess } \\
\text { Heat }^{\mathrm{a}} \\
{[\mathrm{GWh} / \mathrm{yr}]}\end{array}$ & $\begin{array}{l}\mathbf{C O}_{2} \\
\text { Emissions }^{\mathrm{a}} \\
\quad[\mathrm{kton} / \mathrm{yr}]\end{array}$ & $\begin{array}{r}\text { Sites } \\
{[-]} \\
\end{array}$ \\
\hline 1 & Gravel and stones & 834 & 93 & 204 & 101 & 137 \\
\hline 2 & Oil Refineries & 4,513 & 298 & 871 & 1,019 & 5 \\
\hline 3 & Meat & 591 & 483 & 108 & 106 & 81 \\
\hline 4 & Dairy & 1,060 & 508 & 189 & 188 & 73 \\
\hline 5 & Compound feed & 361 & 215 & 43 & 66 & 70 \\
\hline 6 & Sugar & 826 & 103 & 95 & 226 & 2 \\
\hline 7 & Other food & 495 & 316 & 85 & 109 & 144 \\
\hline 8 & Wood & 888 & 217 & 148 & 17 & 235 \\
\hline 9 & Pulp \& Paper & 550 & 170 & 46 & 87 & 114 \\
\hline 10 & Industrial Gasses & 14 & 113 & 0 & 0 & 19 \\
\hline 11 & Enzymes & 214 & 249 & 53 & 42 & 9 \\
\hline 12 & Other chemicals & 161 & 228 & 24 & 31 & 14 \\
\hline 13 & Pharmaceuticals & 359 & 401 & 69 & 84 & 97 \\
\hline 14 & Plastic and rubber & 218 & 516 & 40 & 17 & 356 \\
\hline 15 & Paint \& Soap & 895 & 318 & 91 & 184 & 38 \\
\hline 16 & Cement & 2,575 & 303 & 668 & 881 & 2 \\
\hline 17 & Bricks & 367 & 34 & 78 & 70 & 19 \\
\hline 18 & Asphalt & 430 & 34 & 114 & 84 & 50 \\
\hline 19 & Rockwool & 473 & 95 & 126 & 143 & 17 \\
\hline 20 & Concrete \& other & 811 & 83 & 121 & 161 & 103 \\
\hline 21 & Production of Metal & 451 & 369 & 169 & 84 & 42 \\
\hline 22 & Metalworking & 691 & 486 & 83 & 50 & 946 \\
\hline
\end{tabular}

a Thermal process related.

data may for some units also contain process related $\mathrm{CO}_{2}$ emissions, for example from the calcination of limestone in the cement production. These emissions have to be subtracted if the production units grouped in one industry sector have different amounts of process related $\mathrm{CO}_{2}$ emissions per unit of energy used.

The third allocation step was applied to the majority of the production units with small to medium sizes. This step was performed based on the number of employees registered in the CVR database. The main industrial sectors were divided into sub-sectors and excess heat was distributed amongst them. This step allocated EH to the majority of the units, however only $35 \%$ of the total excess heat. Lastly, for sites where none of the above information was available, a manual check was performed to guarantee that important production units were not discarded.

In Figure 1 the distribution is graphically presented. The inclusion of energy efficiency measures is also shown, as explained in Section 2.1.4. For this analysis, the required input is on one hand industry data for processes, energy use and excess heat on a sector level. On the other hand, site specific data is required, such as energy use, $\mathrm{CO}_{2}$ emissions and employees. Sectoral data is available for 


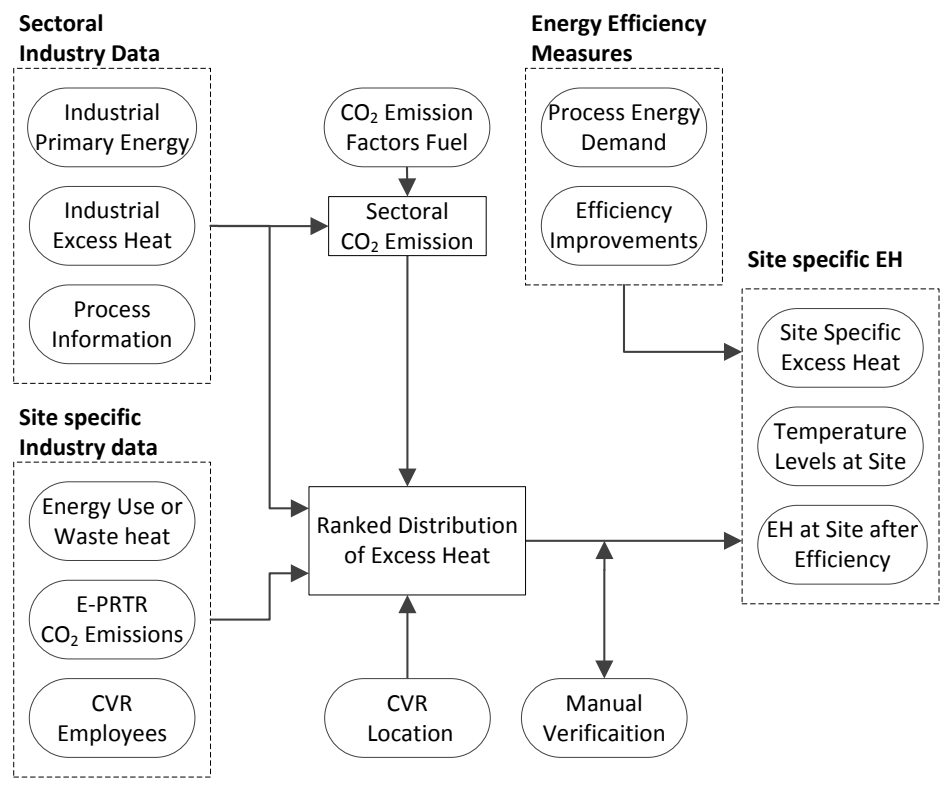

Figure 1: Methodology for the determination of excess heat, temperature levels and avoidable excess heat.

most countries in varying details, whereby the used site specific data is available for most European countries.

The results of the distribution are the EH amounts and EH temperature levels at each production unit in the country. Furthermore EH amounts after possible energy efficiency measures are obtained.

\subsubsection{Utilisation of excess heat}

The utilisation of the EH for district heating depends on the excess heat temperature and the temperature profile of the respective district heating network. The excess heat was divided into two temperature ranges:

(i) Excess heat below $60^{\circ} \mathrm{C}$ which uses water as carrier

(ii) Excess heat above $60^{\circ} \mathrm{C}$ which uses gas as carrier

For the utilisation the minimum temperature difference, $\Delta T_{\text {min }}$, obtainable in the heat exchangers had to be considered. In this work $\Delta T_{\min }$ was chosen to be $10 \mathrm{~K}$ for gases (e.g. flue gases, drying air) as carrying medium of the excess heat and $5 \mathrm{~K}$ for liquids (e.g. condensate). It was assumed that gases may be cooled down to $40^{\circ} \mathrm{C}$, to account for undesirable condensation and minimum stack temperatures. Liquids may be cooled down to the average environmental condition which was set to be $15^{\circ} \mathrm{C}$.

It was further distinguished if the excess heat source can be utilised directly for district heating or if a heat pump is necessary. A combination of direct 
heat transfer and heat pump could increase the system efficiency, however it was neglected in this work. In addition, heat losses from the different components were not included. For heat pumps, the real Coefficient of Performance, $\mathrm{COP}_{\text {real }}$, was based on the Carnot $\mathrm{COP}, \mathrm{COP}_{\text {carnot }}$, and corrected with the heat pump efficiency, $\eta_{H P}$.

$$
\begin{gathered}
C O P_{\text {carnot }}=\frac{T_{D H}+\Delta T_{\text {min }}}{\left(T_{D H}+\Delta T_{\text {min }}\right)-\left(T_{E H}-\Delta T_{\text {min }}\right)} \\
C O P_{\text {real }}=\eta_{H P} C O P_{\text {carnot }}
\end{gathered}
$$

A direct heat transfer is possible when the excess heat temperature, $T_{E H}$, is, $\Delta T_{\min }$ higher than $T_{D H}$.

\subsubsection{Energy efficiency measures in the industry}

To quantify the impact of the future energy efficiency measures in the industry on the EH and thus on the potential for $\mathrm{DH}$, a sensitivity analysis was performed. Kromann et al. [27] estimated the energy efficiency potential for most industries in Denmark. All industry sectors, except oil refineries were included, for which an own analysis was performed using data from similar processes.

The energy efficiency measures were assumed to be directly correlated to excess heat amounts and to cover all thermal processes. Each measure was described by the energy savings when implementing the measure in a process and by the potential for applying this measure to the whole industry (applicability). Table 2 gives an overview of the considered energy efficiency measures for the main process categories. The weighted average energy savings, by which the process energy use was reduced, are given together with the lowest and highest value (stated in the brackets in Table 2) applied to the different industries. The applicability states the fraction of processes for which the energy savings were possible. Thus, the total energy savings for a specific process in a given industry were found by multiplying these two values. The chosen values reflect the energy saving potential obtainable in the medium potential scenario with short payback periods.

\subsection{Spatial Analysis}

The present paper investigates which part of the available excess heat can be fed into the DH networks and consequently supply buildings with heat. This section analyses two factors that can limit the use of EH for DH. First, the installation of a DH network will be limited by the amount of $\mathrm{EH}$ and the distance between the EH source and DH demand. For example, the transmission of heat from a small supermarket over $10 \mathrm{~km}$ is technically possible but the installation of a DH network is probably not economically feasible. We acknowledge this fact by introducing a maximal distance between excess heat sources and district

heating areas. Second, the entire excess heat potential cannot be utilised if the 
Table 2: Overview of energy efficiency measures for different processes, average energy savings and applicability to the sectors.

\begin{tabular}{|c|c|c|c|}
\hline Process & Possible Measures & $\begin{array}{l}\text { Energy } \\
\text { Savings [\%] }\end{array}$ & $\begin{array}{l}\text { Applicability } \\
{[\%]}\end{array}$ \\
\hline Evaporation & Heat pump, Adaptive control & $48(20-90)$ & $26(3-50)$ \\
\hline Heating & $\begin{array}{l}\text { Heat pump, Reduction of tempera- } \\
\text { tures, Overall measures }\end{array}$ & $32(8-55)$ & $27(8-75)$ \\
\hline Drying & $\begin{array}{l}\text { Vacuum drying, Infrared drying, } \\
\text { Steam Drying, Advanced process } \\
\text { control }\end{array}$ & $24(10-60)$ & $20(8-50)$ \\
\hline Total site & $\begin{array}{l}\text { Process integration, Internal use of } \\
\text { excess heat }\end{array}$ & 6 & 82 \\
\hline Utility & Humidification of combustion air & 8 & 5 \\
\hline
\end{tabular}

amount of EH from an industrial facility minus the transmission and distribution losses is larger than the heating demand in a DH area. For example, a large steel factory could supply all buildings within a town. However, if there is no city or a larger town in its vicinity, then it is not possible to utilise the entire excess heat potential.

GIS tools incorporated in ArcGIS 10.4 [28] were applied to find the total heating demand which can be covered by excess heat from industrial facilities. The applied procedure to find this potential was as follows:

1. Excess heat sources (Section 2.1) and official district heating areas [29] were projected on top of a background map in ArcGIS 10.4. Annual district heating statistics published by the Danish District Heating Association [30] were used to assign average annual efficiencies and seasonal supply and return temperatures to district heating areas.

2. The BBR database ${ }^{2}$ with all buildings presented as points were projected on top of the previous layers. This layer contains information about the buildings' heated area, use, construction year and type of heating installations (district heating, natural gas boiler, etc.). The specific heating demand (in $\mathrm{kWh}$ per $\mathrm{m}^{2}$ and year) were assigned to every building based on the construction period and use [31]. The annual heating demands of buildings were calculated as a product of its heated area and specific heating demand. Information about the type of heating installations were used to classify buildings into "DH buildings" and "Not DH buildings".

3. For each excess heat source, the nearest $\mathrm{DH}$ area was identified. It is assumed that the excess heat is delivered to the nearest $\mathrm{DH}$ area.

4. If an industrial excess heat source was located outside of a $\mathrm{DH}$ area, the cut-off distance was identified, i.e. the maximum allowed distance from excess heat source to the nearest DH area. This evaluation took into ac-

\footnotetext{
${ }^{2}$ BBR (in Danish "Bygnings- og Boligregistret") is an acronym for the Danish Register of Buildings and Dwellings.
} 


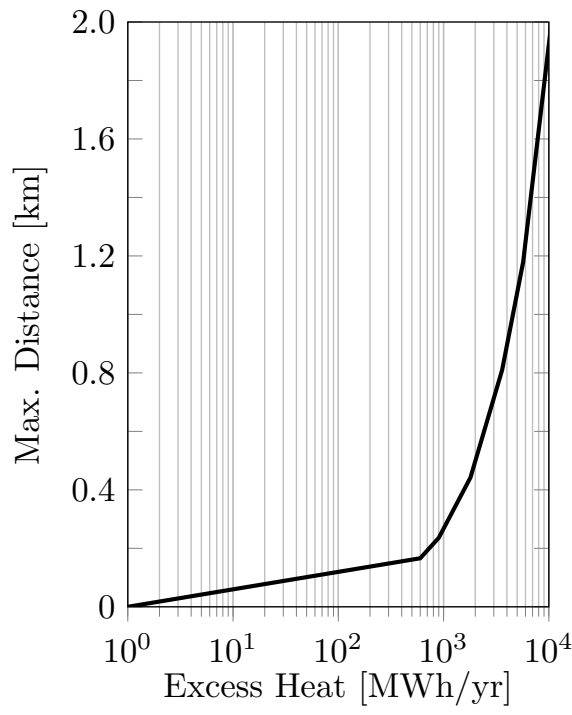

(a) Cut-off distance as a function of $\mathrm{EH}$

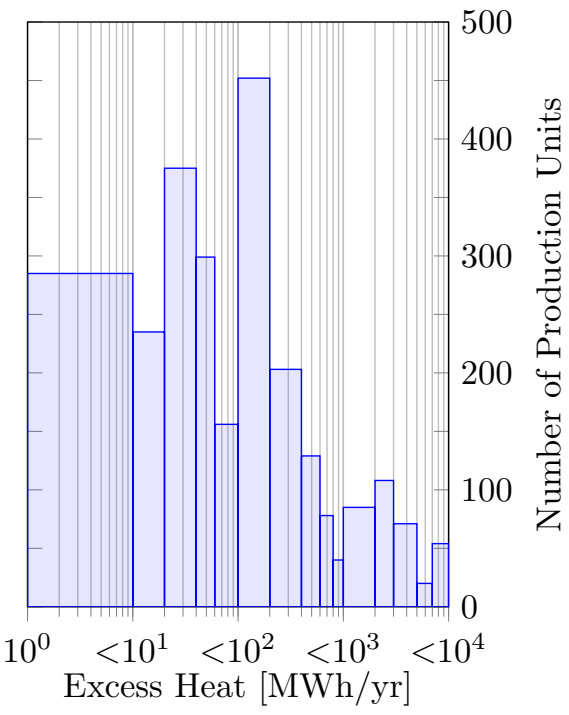

(b) Histogram of units per EH interval

Figure 2: Cut-off distance as a function of the excess heat amount and number of production units within given annual excess heat intervals presented as histogram.

count a maximum connection costs per MWh of heat delivered and the costs for transmission pipes as a function of the capacity [32]. The allowed connection costs were set to 4.17 Euro per MWh per year delivered to the district heating network. This value reflects the cut-off criteria and was chosen based on expected expansion costs of DH areas [33]. Heat sources located within existing DH areas were assumed to be always connectible. Figure 2a shows the cut-off distance of the excess heat sources as a function of the EH size. Figure $2 \mathrm{~b}$ shows the amount of industrial production sites within given excess heat intervals. For example, there are approximately 200 production units with $\mathrm{EH}$ sizes between $200 \mathrm{MWh} / \mathrm{yr}$ and $400 \mathrm{MWh} / \mathrm{yr}$, for which a max. distance of around $150 \mathrm{~m}$ is found. The majority of the EH sources have to be within a close distance (less than 200 meters) to be considered. For some of the largest excess heat emitters, larger distances of above 1000 meters were feasible.

5. If the EH source could be connected to a $\mathrm{DH}$ area, respecting the criteria from point 4 , the deliverable excess heat amount was reduced for transmission and distribution losses. If no $\mathrm{DH}$ area fulfilled the criteria from point 4 , the excess heat was not considered.

6. For each DH area, the following quantities were summarised:

- $\mathrm{HD}_{\mathrm{DH}}$ - Heating demand of "DH buildings"

- $\mathrm{HD}_{\text {not }} \mathrm{DH}$ - Heating demand of "Not DH buildings" 
- $\mathrm{EH}_{\mathrm{DIR}}$ - Heating demand which could be supplied directly from industrial excess heat (without heat pumps)

- $\mathrm{EH}_{\mathrm{HP}}$ - Heating demand which could be supplied from industrial excess heat with heat pumps and

- Electricity needed to run heat pumps.

7. For each $\mathrm{DH}$ area, $\mathrm{HD}_{\mathrm{DH}}, \mathrm{EH}_{\mathrm{DIR}}$ and $\mathrm{EH}_{\mathrm{HP}}$ (calculated in step 6) were compared:

- If $\mathrm{HD}_{\mathrm{DH}}<\mathrm{EH}_{\mathrm{DIR}}$, then $\mathrm{EH}_{\mathrm{DIR}}=\mathrm{HD}_{\mathrm{DH}}$, while $\mathrm{EH}_{\mathrm{HP}}=0$. In this case, a part of the potential for direct use and none of the potential for use of industrial excess heat with heat pumps could be utilised for district heating.

- If $\mathrm{EH}_{\mathrm{DIR}}<\mathrm{HD}_{\mathrm{DH}}<\mathrm{EH}_{\mathrm{DIR}}+\mathrm{EH}_{\mathrm{HP}}$, then $\mathrm{EH}_{\mathrm{DIR}}$ remains the same while $\mathrm{EH}_{\mathrm{HP}}=\mathrm{HD}_{\mathrm{DH}}-\mathrm{EH}_{\mathrm{DIR}}$. In this case, a full potential for direct use and a part of the potential for use of industrial excess heat with heat pumps could be utilised.

- If $\mathrm{HD}_{\mathrm{DH}}>\mathrm{EH}_{\mathrm{DIR}}+\mathrm{EH}_{\mathrm{HP}}, \mathrm{EH}_{\mathrm{DIR}}$ and $\mathrm{EH}_{\mathrm{HP}}$ remain unchanged. In this case, entire industrial excess heat potential could be utilised for district heating.

\section{Results}

First, the results of the geographical mapping of excess heat sources are shown, followed by the potential of using these sources for district heating.

\subsection{Industrial Excess Heat}

The mapping of the industrial excess heat is shown on the national level in Figure 3. The distribution of EH from thermal processes is spatially referenced to the $5 \mathrm{~km}$ by $5 \mathrm{~km}$ Danish square grid. It can be seen that the amount of excess heat varies considerably. The industrial regions around Aalborg, Fredericia, Kalundborg and Frederiksværk have the highest EH amounts. In these areas many companies from the heavy industry are found, such as cement manufacturing, steel processing and oil refineries. Around the Capital Region of Denmark a high density in the amount of industrial production sites are found. These industries however, emit only comparable small amounts of excess heat. The map in Figure 3 further magnifies an exemplary area, where the DH area and location of EH sources are shown.

\subsection{Industrial Excess Heat for District Heating}

The potentials for using $\mathrm{EH}$ for $\mathrm{DH}$ are presented in Figure 4. From the theoretical maximum excess heat potential of $3.43 \mathrm{TWh}$ per year, $1.36 \mathrm{TWh}$ of

district heat can be supplied to the consumers. The theoretical excess heat potential is reduced by more than $1 \mathrm{TWh} / \mathrm{yr}$ (from $3.4 \mathrm{TWh} / \mathrm{yr}$ to $2.4 \mathrm{TWh} / \mathrm{yr}$ ), 


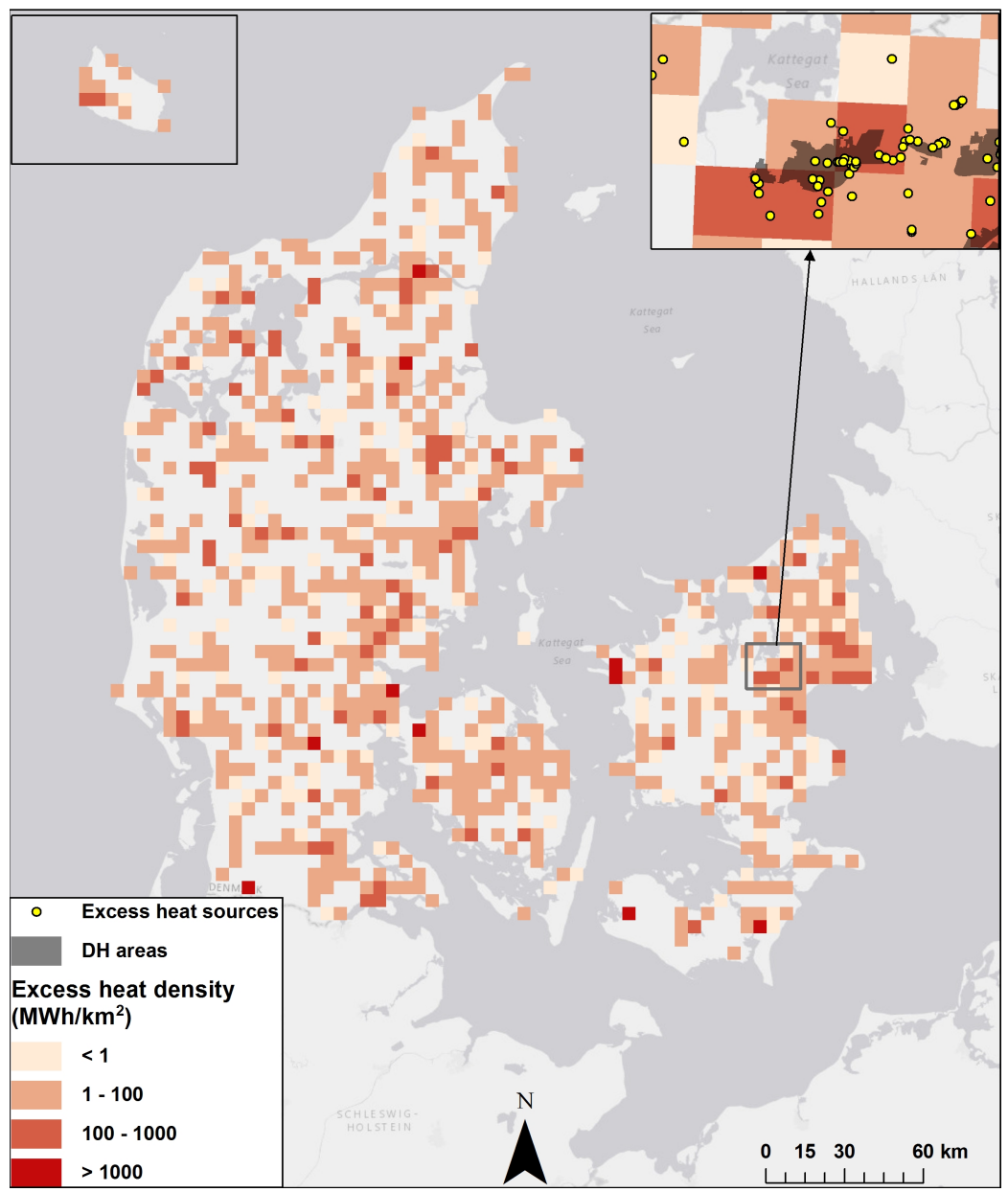

Figure 3: Excess heat from industrial thermal processes within $5 \mathrm{~km}$ by $5 \mathrm{~km}$ Danish Square Grid and example of data in the Roskilde area.

when the potential is corrected for inaccessible excess heat and unusable low temperature heat. This correction is mainly based on $\mathrm{EH}$ from flue gases which cannot be recovered and the limit of $40^{\circ} \mathrm{C}$ for cooling down gases.

However, not all excess heat is available for use in the DH networks. The recovery of the accessible excess heat is further reduced by considering network losses and eliminating excess heat sources which are outside of the cut-off distance. As shown in Figure 4, after the losses in district heating networks are taken into account, the heat which can be delivered is estimated to $1.88 \mathrm{TWh}$ per year. The share of heat which cannot be economically transmitted to $\mathrm{DH}$ networks, due to large distances reduces the annual potential by $0.29 \mathrm{TWh}$ (to $1.59 \mathrm{TWh}$, third bar in Figure 4). To obtain the real potential, the excess heat which cannot be used due to a lack of demand is taken out $(0.23 \mathrm{TWh} /$ year). 


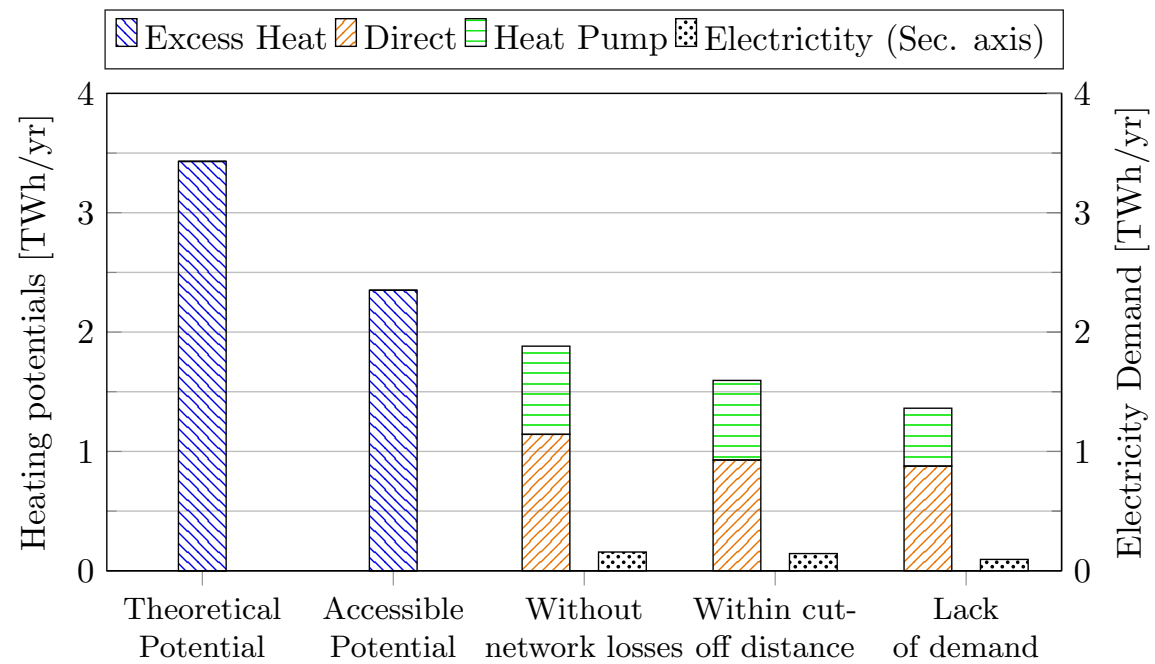

Figure 4: Potentials for supplying district heating demand from industrial excess heat sources.

In certain cases, there is not enough DH demand even though large excess heat sources are available. This limits district heating demand that can be covered from excess heat sources to $1.36 \mathrm{TWh} / \mathrm{yr}$ or around $5.1 \%$ of the existing $\mathrm{DH}$ demand (the most right bar in Figure 4). The remaining $0.23 \mathrm{TWh} / \mathrm{yr}$ can be used for connecting the remaining consumers within DH areas to DH. The final annual potential of district heating supplied to the consumers is divided into $0.88 \mathrm{TWh}$ originating from direct recovery and $0.49 \mathrm{TWh}$ from heat recovery using a heat pump. The heat pumps would require $0.1 \mathrm{TWh} / \mathrm{yr}$ of electricity, thus operating at an average COP of 5 when assuming a Carnot efficiency of $55 \%$.

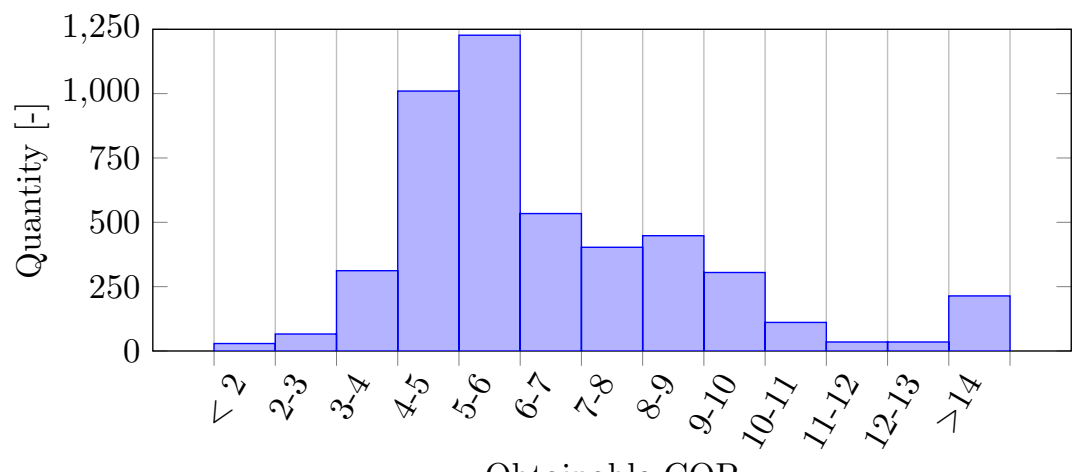

Obtainable COP

Figure 5: Distribution of the obtainable COP values for matches between excess heat and district heating networks. 
The distribution of the obtainable COPs for the connection of heat sources to the district heating networks is shown in Figure 5. With the majority of the matches, COPs of between 4 and 6 could be obtained. Almost as many matches are found in the range of COPs from 6 to 10. The obtainable COP can give an indication of the required relation between electricity and heating prices, for a profitable operation of the system.

Table 3: District heating demand and demand covered by excess heat directly or with a heat pump inside and outside the cut-off distance.

\begin{tabular}{|c|c|c|c|c|c|c|c|}
\hline \multirow{3}{*}{ Region } & \multirow{3}{*}{$\begin{array}{r}\text { DH Demand } \\
{[\mathrm{TWh} / \mathrm{yr}]}\end{array}$} & \multicolumn{3}{|c|}{ EH within cut-off } & \multicolumn{3}{|c|}{ EH outside cut-off } \\
\hline & & Direct & HP & /DH & Direct & & $\mathrm{PEH} / \mathrm{DH}$ \\
\hline & & Wh/yr] & TWh/yr] & {$[\%]$} & {$[\mathrm{TWh} / \mathrm{yr}]$} & {$[\mathrm{TWh} / \mathrm{yr}]$} & {$[\%$} \\
\hline Central DKE & 7.73 & 0.072 & 0.123 & 2.5 & 0.008 & 0.003 & 0.1 \\
\hline Decentral DKE & 2.68 & 0.102 & 0.027 & 4.8 & 0.028 & 0.014 & 1.6 \\
\hline Central DKW & 9.18 & 0.511 & 0.312 & 9.0 & 0.014 & 0.007 & 0.2 \\
\hline Decentral DKW & 7.07 & 0.192 & 0.023 & 3.0 & 0.157 & 0.037 & 2.7 \\
\hline Total & 26.66 & 0.877 & 0.485 & 5.1 & 0.207 & 0.061 & 1.0 \\
\hline
\end{tabular}

In Table 3 the $\mathrm{DH}$ demand and substitution potential with $\mathrm{EH}$ is allocated to East Denmark (DKE) and West Denmark (DKW). A subdivision in central and decentral areas is further made. It can be observed that the distances between excess heat sources and district heating demand are especially important in decentral areas. Namely, $25 \%$ and $50 \%$ of available excess heat in East and West Denmark cannot be utilised because it is too far from the demand to be economically feasible.

The maximum coverage (EH/DH) from excess heat sources is $9 \%$ and can be achieved in central district heating areas in DKW. After all constraints are taken into account, it is found that $5.1 \%$ of district heating demand can be supplied from industrial excess heat.

The share of DH demand which can be replaced by industrial excess heat from thermal processes is shown on the map in Figure 6. Several large district heating networks, such as the networks in Aalborg, Kalundborg and the South of Copenhagen, could have a high share (over $80 \%$ ) of their DH demand covered by EH. 


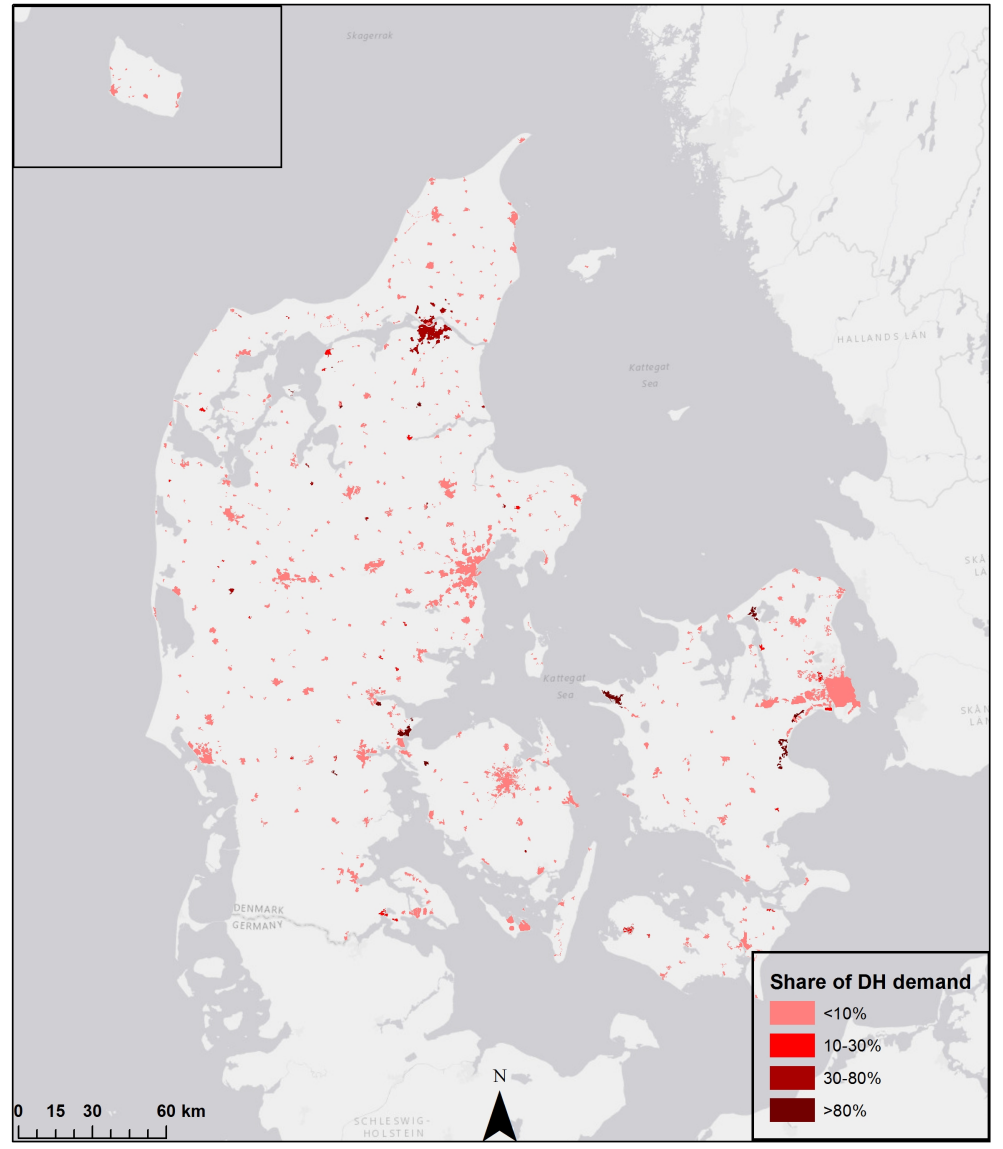

Figure 6: Danish district heating areas and the possible share of DH demand supplied by excess heat.

\section{Sensitivity Analysis}

The share of district heating demand which can be supplied by industrial excess heat is dependent on several factors. First, the excess heat source can change as a result of efficiency improvements. Second, the transmission and distribution of $\mathrm{EH}$ through district heating network is also subject to change. Third, the district heating consumers can change as a result of heat saving measures. The most influential parameters for the utilisation of industrial excess heat for district heating are therefore varied in order to discover the sensitivity of the results. For each of the 23 sensitivity actions, the following variables are compared with their values calculated in Section 3:

- Share of district heating demand which can be supplied by industrial excess heat. 
- Share of district heating demand which could be supplied from industrial excess heat but which is too far away (outside of the calculated cut-off distance).

Both variables are expressed as a share of the existing district heating demand. The sensitivity actions imply a combination of changes of the following input parameters:

- Efficiency improvements and internal reuse of energy in industries, as described in Section 2.1.4. The rationale is that energy efficiency improvements with a likely implementation potential will be performed before looking into the possibility of generating district heating. In this way the available excess heat is reduced.

- Efficiency increase of DH transmission and distribution of 5 percent points is assumed for all district heating networks. Reduction of supply and return temperatures, lower losses and integration of various heat sources in DH networks are necessary to reach the $4^{\text {th }}$ generation of district heating systems [34].

- Reduction of district heating demand by $30 \%$ and $50 \%$, as a result of heat saving measures, demolition of existing and construction of new energyefficient buildings. Even though this is not a realistic sensitivity action in the short term, it shows how important the demand side is.

- Buildings which are located within existing district heating areas but are not supplied by DH are included as a potential heating demand. According to several studies, expansion of district heating should start from these buildings $[5,6,7]$.

The summary of the sensitivity analysis is presented in Figures 8 to 11. The results presented in Section 3 are confirmed when the sensitivity analysis is undertaken. In each of the figures, the $\mathrm{DH}$ demand which can be supplied by industrial excess heat is presented alongside the $\mathrm{DH}$ demand which could be supplied by industrial excess heat but is further away than the cut-off distances. The left half of Figures 8 to 11 (named "Buildings supplied by DH") includes only buildings currently supplied by DH, while the right half (named "All buildings within DH areas") also includes the buildings which are currently not supplied by DH. For illustration, Figure 7 is presented - buildings supplied by DH are depicted by green points, other buildings located within DH area are depicted by red points, while the buildings located outside of $\mathrm{DH}$ areas (black points) are not considered as candidates for connection to $\mathrm{DH}$ in this analysis.

Figure 8 presents the heating demand which can be supplied by industrial excess heat if the EH sources and DH grid are kept constant, while the heating demand is decreased by $30 \%$ and $50 \%$. The maximum heating demand which can be supplied by excess heat is $9.1 \%$ of the district heating demand. This is the case when the heating demand in buildings is reduced by $50 \%$ and all 


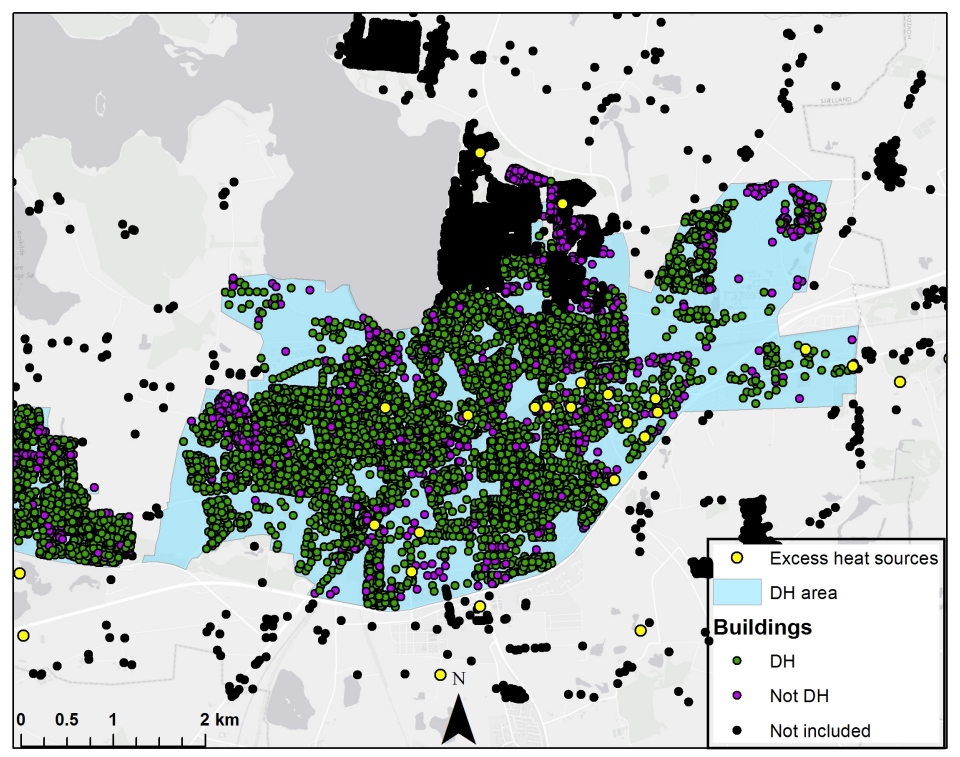

Figure 7: DH area, EH sources and buildings within and outside of the DH area in the vicinity of the city of Roskilde.

buildings with $\mathrm{DH}$ areas are considered as candidates for connection to DH. It could be expected that the reduction of heating demand by $50 \%$ results in doubling of the heating demand which can be supplied by excess heat. This is correct for $\mathrm{DH}$ areas in which the demand is a lot higher than the available $\mathrm{EH}$. On the other hand, if the available $\mathrm{EH}$ is greater than the demand, the reduction in demand will not change the potential coverage of heating demand with excess heat - it stays at $100 \%$.

The effect of energy efficiency improvements in industries on the utilisation of industrial excess heat for DH is presented in Figure 9. As expected, the energy efficiency improvements in industries are reducing the $\mathrm{EH}$ available for $\mathrm{DH}$. However, when compared to Figure 8, it can be concluded that the effect on the amount of EH which can be supplied to consumers is not major. The same conclusion holds true for the heating demand located outside of the calculated cut-off distances.

The "delivered-energy" weighted efficiency of DH networks in Denmark is $80.6 \%$ [2]. The effect of increased energy efficiency of district heating grids by 5 percent points on the $\mathrm{DH}$ demand which can be supplied by industrial excess heat can be seen from Figure 10. It would be reasonable to expect that the increase in efficiency of transmission and distribution from $80.6 \%$ to $85.6 \%$ would be linearly translated into the potential for supplying demand by EH by $6.2 \%(85.6 \% / 80.6 \%-1=6.2 \%)$. However, the demand which can be supplied by $\mathrm{EH}$ increases between $4.4 \%$ and $5 \%$ depending on the sensitivity measure. 


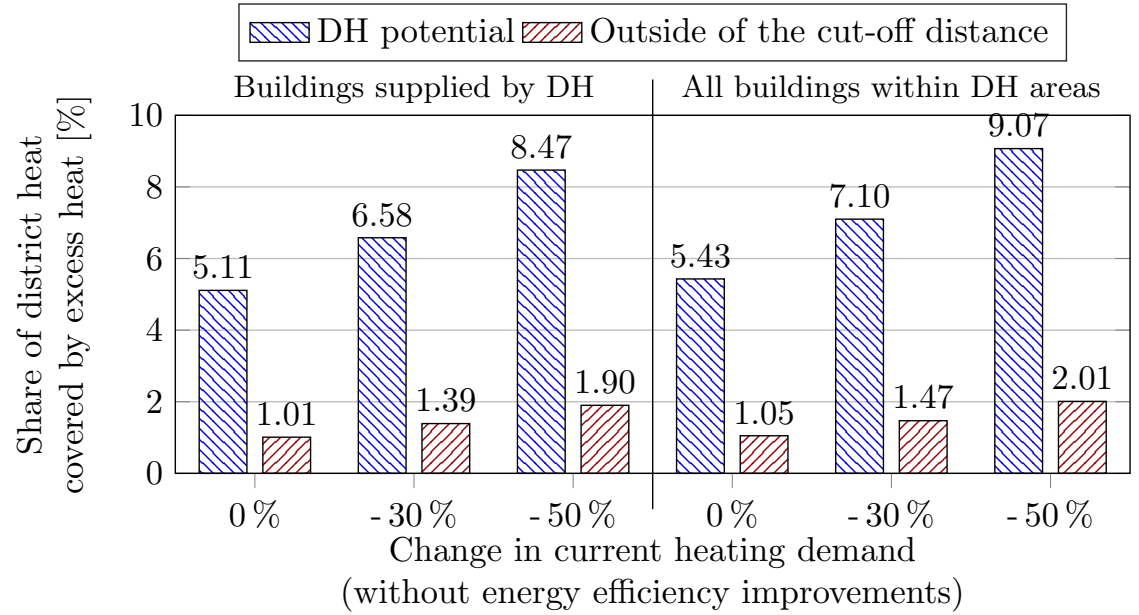

Figure 8: Potential for supplying DH demand by industrial excess heat for different heating demands.

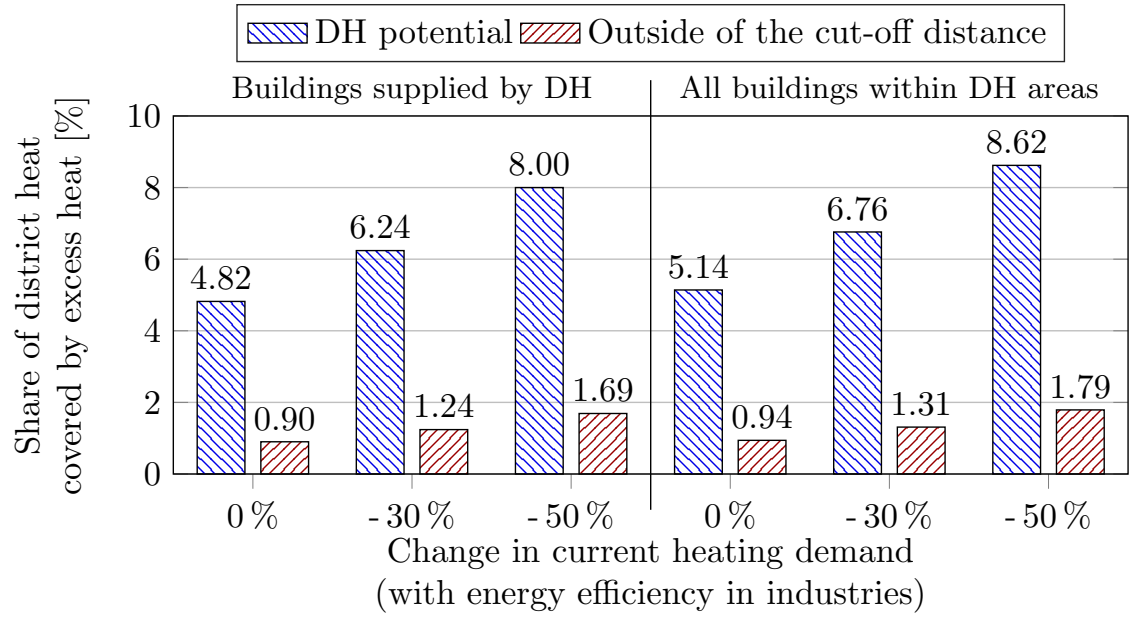

Figure 9: Potential for supplying DH demand by industrial excess heat for different heating demands and excess heat amounts.

This is due to $\mathrm{DH}$ grids in which the $\mathrm{EH}$ is larger than the $\mathrm{DH}$ demand.

The combined effect of energy efficiency improvements in industries and district heating grids on the utilisation of industrial excess heat for DH is presented in Figure 11. The energy efficiency improvements in industries are reducing the $\mathrm{EH}$, thus reducing the amount of $\mathrm{DH}$ that can reach the consumers. The efficiency improvements in DH grids have the opposite effect. If Figure 11 is compared with Figure 8, it can be seen that these two processes are cancelling each other out. 


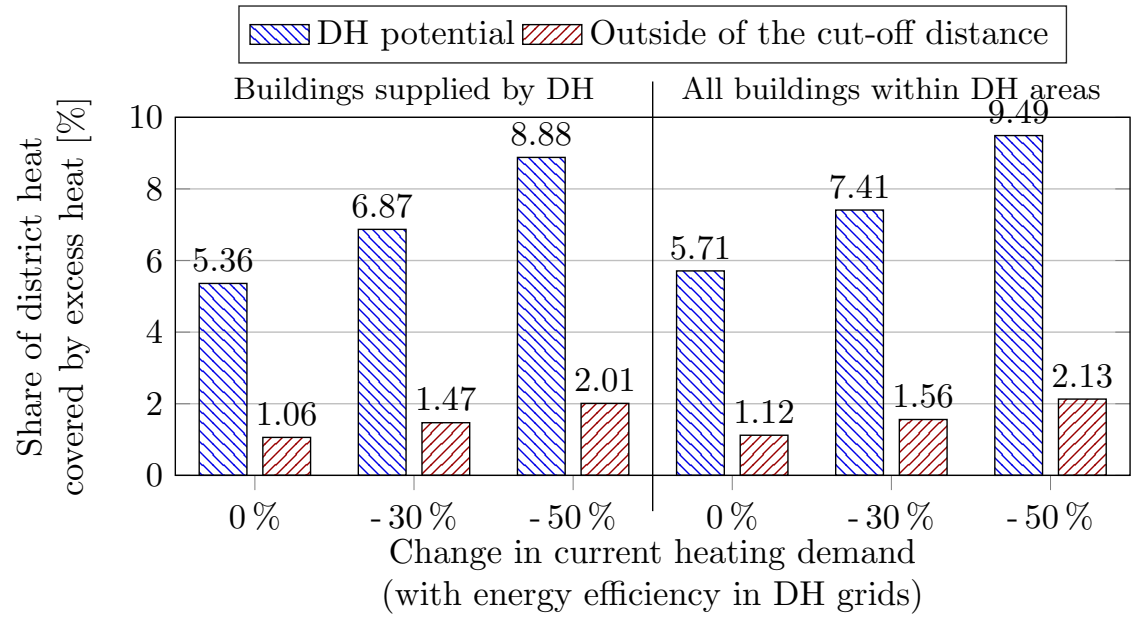

Figure 10: Potential for supplying DH demand by industrial excess heat for different heating demands and efficiencies of DH grids.

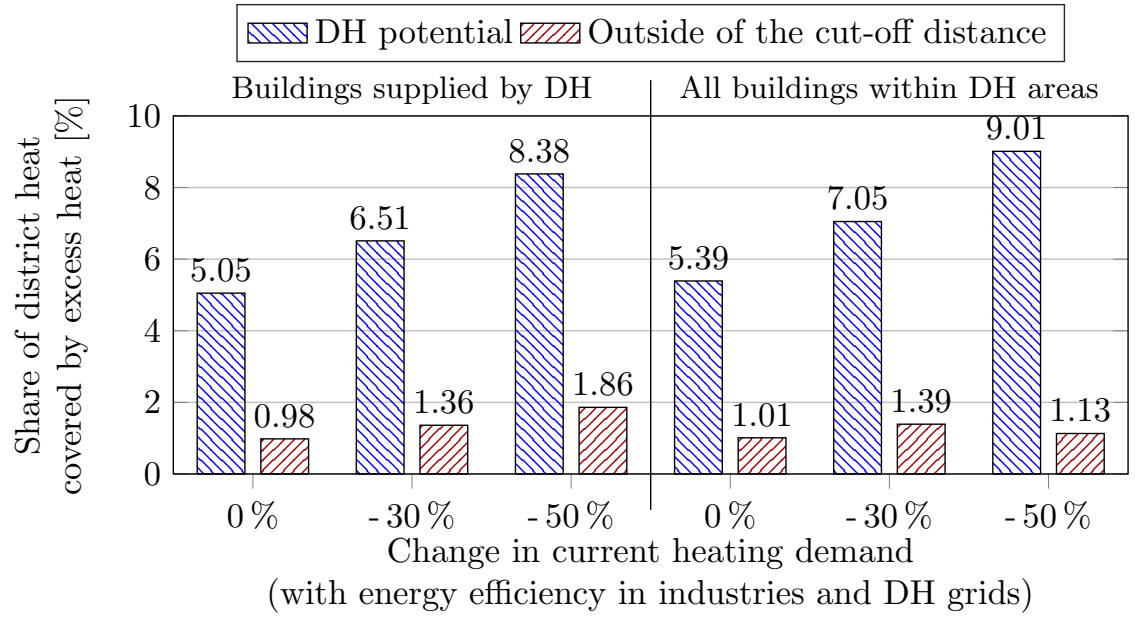

Figure 11: Potential for supplying DH demand by industrial excess heat for different heating demands, excess heat amounts and efficiencies of DH grids.

\section{Discussion}

This work found that 2.37 TWh of accessible industrial excess heat could supply 1.36 TWh of DH to consumers per year. This is in line with $2.65 \mathrm{TWh} / \mathrm{yr}$ used in Ref. [9], $30 \%$ smaller than $3.44 \mathrm{TWh} / \mathrm{yr}$ used in [22, 23] and $80 \%$ higher than 1.31 TWh used in the energy scenarios up to 2020, 2035 and 2050 published by the Danish Energy Agency [12]. However, 1.31 TWh/yr used in [12] is not directly comparable as it refers to the years 2035 and 2050. Contribution of industrial excess heat to supplying heating demand in Ref. [7] is between 
$83 \mathrm{GWh} / \mathrm{yr}$ and $153 \mathrm{GWh} / \mathrm{yr}$, which is significantly smaller than $1.36 \mathrm{TWh} / \mathrm{yr}$ estimated in the present study. Industrial excess heat is not included in studies $[5,6,9]$, while the excess heat in Ref. [10] comes from biorefineries, which do not currently exist in Denmark and is therefore not comparable.

The numbers used for EH as a resource in the different works are hardly comparable, as system boundaries are chosen differently and often the background of the numbers is not clearly stated. In this work a detailed mapping of excess heat and its temperatures has been performed, which only considers part of the industry but with a high level of detail.

Even though a detailed mapping of EH and linking of sources and demands has been performed, a couple of factors were not included. As only excess heat from thermal processes in 22 industrial sectors was taken into account, the total potential for district heat could be even higher. The total accessible excess heat potential from the manufacturing industry used in this study was $2.37 \mathrm{TWh} / \mathrm{yr}$, which is lower than the excess heat potential found for the whole industry. A previous comparable study [35], which also included EH from other processes and industries found an annual excess heat potential of 6.27 TWh. On the other hand, the actual potential for utilising excess heat can be smaller due to variations of excess heat sources and demand over shorter and longer time periods, taxes and polices, local and technical barriers.

The role of industrial excess heat in the future energy system, i.e. its effect on the investment and operation costs, fuel use, environmental emissions, etc. can be quantified by the use of energy system analysis tools. However, even if the energy systems analysis tools show that the utilisation of industrial excess heat is beneficial for the energy system as a whole, it needs to be ensured that these solutions also perform the best from a business-economic perspective. This can be done by introducing relevant supporting schemes, taxes and regulations.

Not even well defined taxes and polices guarantee that the district heating companies will be willing to accept the industrial excess heat. The risk of industrial facilities changing production, closing or relocating, might not be accepted by district heating companies. Therefore, there is a need for the analysis of business models for utilisation of industrial excess heat.

The systematic approach developed in the present work could also be applicable and beneficial to other countries and regions. Even though the data is usually not available with such a high level of details as in Denmark, this systematic approach can be adjusted to account for a higher order of aggregation in the data.

\subsection{Geographic distribution of excess heat}

It is necessary to further evaluate the precision at which the distribution of the excess heat amongst single production units was conducted. A detailed analysis of the dairy sector was previously performed. For the majority of the dairy sites in Denmark, detailed information for total energy input, thermal and electric energy use for processes and facilities, raw material input and boiler and distribution losses were available. This information was gathered on 
a site-specific level.

Figure 12 shows a comparison of the applied method to allocate $\mathrm{EH}$ to each production site based on $\mathrm{CO}_{2}$ emissions or number of employees. For each site, the $\mathrm{EH}$ was also distributed based on the real thermal process and total energy demand. In addition the thermal losses from boilers (excluding the production of electricity) and distribution losses in the factories steam network are shown.

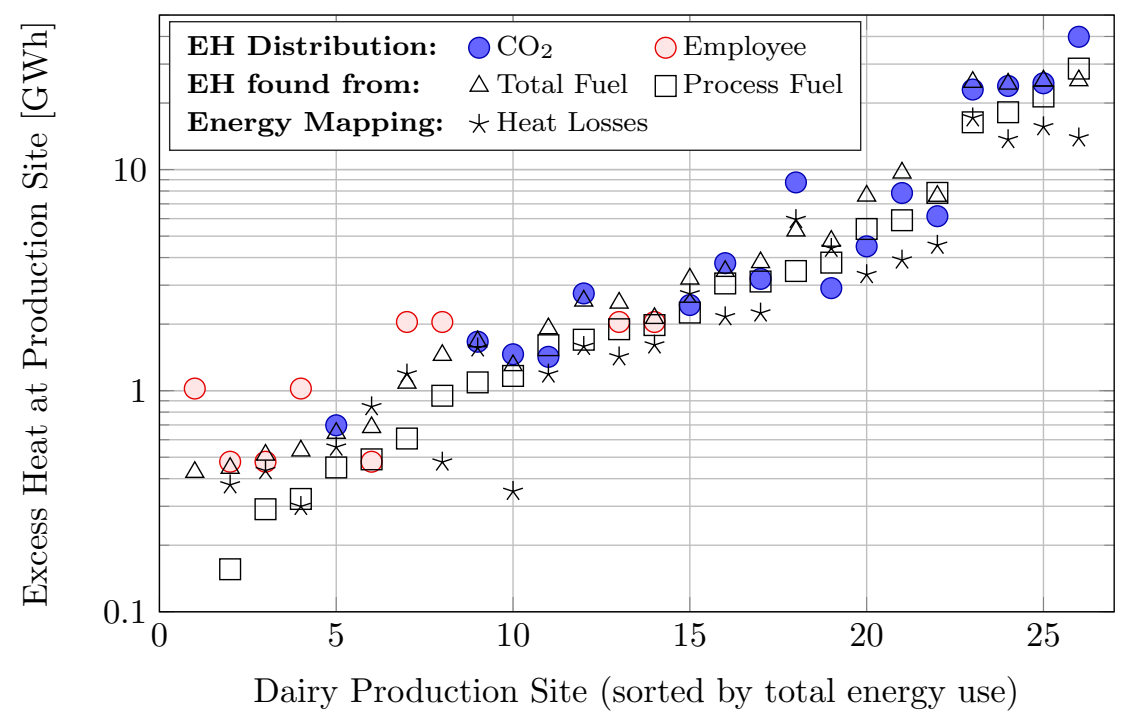

Figure 12: Comparison of allocated excess heat based on $\mathrm{CO}_{2}$ emissions or number of employees to data obtained by energy mappings at the individual sites.

It can be seen that for sites with a low energy use, where the number of employees was used, the EH tends to be slightly overestimated with the proposed method. For energy intense sites, the $\mathrm{EH}$ allocated with $\mathrm{CO}_{2}$ emissions correlates closely, with a tendency of underestimation, to the distribution using the real process energy demands.

The boiler and distribution losses were at most sites lower than the total excess heat allocated. Other sources of EH exist at the site, especially for large units. For example, the production of milk powder results in considerable excess heat from drying and evaporation facilities.

For the production of asphalt, site-specific $\mathrm{CO}_{2}$ emissions were not available. The distribution relied solely on the number of employees registered and is thus expected to be the most uncertain distribution. For two factories in Denmark, the actual excess heat of the direct fired rotary dryers were known based on a detailed analysis. The dryer is the primary source of excess heat in the production of asphalt [36]. For the first factory excess heat of $2.69 \mathrm{GWh}$ per year and for the second one $0.89 \mathrm{GWh}$ per year were found. The distribution of excess heat using the proposed method, allocated $3.83 \mathrm{GWh}$ per year to each of the 
two factories. The difference between the estimated and actual EH amount, shows that the order of magnitude is comparable and a reliable indication can be given. For companies manufacturing the same product and employing a comparable number of people, the real EH amount may however be different. This is not represented when performing the EH allocation based on employees registered in the CVR.

\section{Conclusion}

This work analyses excess heat sources from the industrial sector in Denmark and how they could be used for district heating. The developed method quantifies excess heat at single production units, together with industry specific temperature profiles and performs spatial analysis to link excess sources with buildings.

The results for the case study of Denmark show that $5.1 \%$ of the existing district heating demand could be supplied with industrial excess heat from thermal processes. This potential is not uniform, it is high in industrial regions around Aalborg, Fredericia and Kalundborg, while it is low in the Capital region. This means that industrial excess heat cannot be a dominant source of district heating on the national level, but can be very important in some local district heating systems.

In total $1.36 \mathrm{TWh}$ per year of district heat could be supplied from industrial excess heat. A heat pump was required for $36 \%$ of this district heat, as the temperature of the excess heat source was too low. The required heat pumps would operate at an average $\mathrm{COP}$ of above 5 , thus requiring $0.1 \mathrm{TWh} / \mathrm{yr}$ of electric energy.

The spatial analysis enabled to investigate the maximum distances between excess heat sources and the demand and the situation when the excess heat is larger than the heating demand. Both proved significant as each of them reduces the available excess heat by $15 \%$.

The sensitivity analysis showed that the results are not very sensitive to the considered efficiency improvements in the industry, district heating grids and buildings. The simultaneous reduction of heating demand in buildings by $50 \%$ and increasing the efficiency of district heating grids by 5 percent points has the highest impact. In this case, industrial excess heat can supply $8.9 \%$ of district heating demand in buildings. The effect of efficiency improvements in the grids and in the industry are cancelling each other out.

\section{Acknowledgement}

A part of the work presented in this paper is a result of the research activities of the Strategic Research Centre for 4th Generation District Heating (4DH), which has received funding from Innovation Fund Denmark. 


\section{References}

[1] Danish Energy Agency, Data, Tables, Statistics and Maps, Energy in Denmark, 2015. URL: https://ens.dk/service/ statistik-noegletal-og-kort/energipriser-og-afgifter.

[2] Euroheat \& Power, District Heating and Cooling Country by Country Survey 2015, Technical Report, 2015. URL: https://www.euroheat.org/ publications/country-by-country/.

[3] Danish Ministry of Climate Energy and Building, The governments' energy and climate political goals and the results of the energy agreement in 2020, 2012. URL: http://www.efkm.dk/publikationer/.

[4] Danish Ministry of Climate Energy and Building, Our Energy (In Danish), 2011. URL: http://www.stm.dk/multimedia/Vores\{_\}energi.pdf.

[5] M. Münster, P. E. Morthorst, H. V. Larsen, L. Bregnbæk, J. Werling, H. H. Lindboe, H. Ravn, The role of district heating in the future Danish energy system, Energy 48 (2012) 47-55.

[6] H. Lund, B. Möller, B. V. Mathiesen, A. Dyrelund, The role of district heating in future renewable energy systems, Energy 35 (2010) 1381-1390.

[7] B. Möller, H. Lund, Conversion of individual natural gas to district heating: Geographical studies of supply costs and consequences for the Danish energy system, Applied Energy 87 (2010) 1846-1857.

[8] B. V. Mathiesen, H. Lund, K. Karlsson, 100\% Renewable energy systems, climate mitigation and economic growth, Applied Energy 88 (2011) 488501.

[9] B. V. Mathiesen, H. Lund, D. Connolly, Limiting biomass consumption for heating in 100\% renewable energy systems, Energy 48 (2012) 160-168.

[10] K. B. Karlsson, S. N. Petrovic, R. Næraa, Heat supply planning for the ecological housing community Munksøgård, Energy 115 (2016) 1733-1747.

[11] Danish Energy Agency, Energiproducenttælling (Energy producers count) 2010-2012, 2014. URL: https://ens.dk/service/ statistik-data-noegletal-og-kort/.

[12] Danish Energy Agency, Energistyrelsen, Danmarks Energi - og Klimafremskrivning 2014, 2014. URL: http://www.ens.dk/info/tal-kort/ fremskrivninger-analyser-modeller/fremskrivninger.

[13] L. Miró, S. Brückner, L. F. Cabeza, Mapping and discussing Industrial Waste Heat (IWH) potentials for different countries, Renewable and Sustainable Energy Reviews 51 (2015) 847-855. 
[14] T. Naegler, S. Simon, M. Klein, H. C. Gils, Quantification of the European industrial heat demand by branch and temperature level, International Journal of Energy Research 39 (2015) 2019-2030.

[15] S. Brückner, L. Miró, L. F. Cabeza, M. Pehnt, E. Laevemann, Methods to estimate the industrial waste heat potential of regions - A categorization and literature review, Renewable and Sustainable Energy Reviews 38 (2014) 164-171.

[16] S. Brückner, S. Liu, L. Miró, M. Radspieler, L. F. Cabeza, E. Lävemann, Industrial waste heat recovery technologies: An economic analysis of heat transformation technologies, Applied Energy 151 (2015) 157-167.

[17] S. Broberg, S. Backlund, M. Karlsson, P. Thollander, Industrial excess heat deliveries to Swedish district heating networks: Drop it like it's hot, Energy Policy 51 (2012) 332-339.

[18] S. B. Viklund, M. T. Johansson, Technologies for utilization of industrial excess heat: Potentials for energy recovery and $\mathrm{CO} 2$ emission reduction, Energy Conversion and Management 77 (2014) 369-379.

[19] G. P. Hammond, J. B. Norman, Heat recovery opportunities in UK industry, Applied Energy 116 (2014) 387-397.

[20] S. J. G. Cooper, G. P. Hammond, J. B. Norman, Potential for use of heat rejected from industry in district heating networks, Gb perspective, Journal of the Energy Institute 89 (2016) 57-69.

[21] R. C. McKenna, J. B. Norman, Spatial modelling of industrial heat loads and recovery potentials in the UK, Energy Policy 38 (2010) 5878-5891.

[22] U. Persson, B. Müller, S. Werner, Heat Roadmap Europe: Identifying strategic heat synergy regions, Energy Policy 74 (2014) 663-681.

[23] R. Lund, U. Persson, Mapping of potential heat sources for heat pumps for district heating in Denmark, Energy (2016).

[24] F. Bühler, T.-V. Nguyen, B. Elmegaard, Energy and exergy analyses of the Danish industry sector, Applied Energy 184 (2016) 1447-1459.

[25] F. Bühler, F. M. Holm, B. Huang, J. G. Andreasen, B. Elmegaard, Mapping of low temperature heat sources in Denmark, in: 28th International Conference on Efficiency, Cost, Optimization, Simulation and Environmental Impact of Energy Systems, 2015.

[26] Statistics Denmark, ENE2HA: Energy Account in common units (detailed table) by use and type of energy, 2015. 
[27] M. Kromann, H. Kragerup, M. Dalsgaard, Kortlægning af Energisparepotentialer i Erhverslivet (Mapping of Energy Saving Potentials in Industry and Commerce), Technical Report, COWI A/S, 2015. URL: https: //ens.dk/ansvarsomraader/energibesparelser.

[28] Environmental Systems Research Institute (ESRI), ArcGIS Desktop: Release 10.4, 2017. URL: https://desktop.arcgis.com/.

[29] Danish Business Authority, Collective heating supply 2017 [in Danish], 2017. URL: https://erhvervsstyrelsen.dk/ kollektiv-varmeforsyning.

[30] Danish District Heating Association, Annual district heating statistics 2015/2016 [in Danish], 2016. URL: www.danskfjernvarme.dk/viden-om/ aarsstatistik/statistik-2015-2016.

[31] K. B. Wittchen, J. Kragh, S. Aggerholm, Potential heat savings during ongoing renovations of buildings until 2050, Technical Report, SBi Danish Building Research Institute, 2016. URL: http://www.sbi.dk/ miljo-og-energi/energibesparelser/.

[32] S. Nielsen, B. Müller, GIS based analysis of future district heating potential in Denmark, Energy 57 (2013) 458-468.

[33] Danish Energy Agency, Technology Data for Energy Plants - Generation of Electricity and District Heating, Energy Storage and Energy Carrier Generation and Conversion, Technical Report March, 2015. URL: https://ens . $\mathrm{dk} /$ en/our-services/projections-and-models/technology-data.

[34] H. Lund, S. Werner, R. Wiltshire, S. Svendsen, J. E. Thorsen, F. Hvelplund, B. V. Mathiesen, 4th Generation District Heating (4GDH). Integrating smart thermal grids into future sustainable energy systems., Energy 68 (2014) 1-11.

[35] B. Huang, F. Bühler, F. M. Holm, Industrial Energy Mapping: THERMCYC WP6, Technical Report, Technical University of Denmark, 2015.

[36] T. D. Miller, H. U. Bahia, Sustainable Asphalt Pavements: Technologies, Knowledge Gaps and Opportunities, Technical Report, University of Wisconsin-Madison, 2009. URL: http://uwmarc.wisc.edu/files/ MARC-Sustainable-Asphalt-Pavements-white-paper.pdf. 